\title{
Effects of captopril in patients with chronic obstructive pulmonary disease and secondary pulmonary hypertension
}

\author{
D. Patakas, D. Georgopoulos, H. Rodini and P. Christaki
}

Pulmonary Clinic, Department of Internal Medicine, University of Thessaloniki, Thessaloniki, Greece.

\begin{abstract}
Summary: Ten patients with chronic obstructive pulmonary disease (COPD) with normal left ventricular function were given a single dose of captopril $(0.25 \mathrm{mg} / \mathrm{kg})$. Mean systemic arterial pressure, heart rate and coronary flow to the right ventricle were reduced significantly after captopril. In contrast captopril did not cause a significant fall in pulmonary arterial pressure or pulmonary vascular resistance. We conclude that captopril fails to produce haemodynamic benefits in such hypoxic patients and that angiotensin II is not playing a significant role in maintaining pulmonary vasoconstriction.
\end{abstract}

\section{Introduction}

Captopril, an angiotensin converting enzyme (ACE) inhibitor is effective in the treatment of congestive cardiac failure resistant to other drugs; captopril increases cardiac output and reduces mean arterial pressure, systemic vascular resistance, right atrial pressure and pulmonary artery and pulmonary wedge pressures in patients with congestive heart failure. ${ }^{1}$ The beneficial effects seem to relate to the pretreatment plasma renin activity. ${ }^{2,3}$ The potential ' role of ACE inhibition in pulmonary hypertension secondary to chronic obstructive pulmonary disease (COPD) has also been investigated. ${ }^{4,5,6}$

Angiotensin II exerts a powerful vasoconstrictive action on the pulmonary circulation. ${ }^{7}$ The humoral mediators involved in eliciting and maintaining hypoxic pulmonary hypertension are as yet ill defined but it has been demonstrated that COPD patients have elevated plasma levels of renin, angiotensin II and arginine vasopressin. ${ }^{8}$ In order to investigate the possible role of angiotensin II in patients with the above conditions we studied the acute haemodynamic changes induced by oral captopril.

\section{Material and methods}

Ten patients $(8$ men) mean age ( \pm s.d.) $63.8 \pm 9.2$ years, with chronic obstructive pulmonary disease ( $\%$ forced expiratory volume in one second $\left[\mathrm{FEV}_{1}\right]$

Correspondence: D. Patakas, M.D.

Accepted: 24 November 1987
$44 \pm 9 \%)$ and respiratory failure gave informed consent to the present investigation. Their mean forced expiratory volume in one second was $29.5 \%$ +9.5 (s.d.) of predicted. All patients had congestive heart failure due to pulmonary hypertension. None had evidence of left ventricular failure.

The patients were in the fasting state, all medications and supplemental oxygen having been stopped for 12 hours. A triple lumen thermodilution SwanGanz catheter (7F, Edwards Lab) was placed into a pulmonary artery under constant pressure wave monitoring. A small polyethylene catheter was inserted into a radial artery. Pulmonary and systemic vascular pressures were measured using Staham p $23 \mathrm{Db}$ transducers. Cardiac output was measured in triplicate using a Gould cardiac output computer. Arterial and mixed blood gases were measured using the Radiometer Co automatic $\mathrm{pH} /$ blood gas system. Haemoglobin levels and oxygen saturation were determined using the OSM2 haemoximeter (Radiometer Co).

Expiratory gas flow and volumes were measured with a vitalograph. The following parameters were obtained sequentially: Cardiac output (CO); pulmonary artery mean ( (mPAP), wedge (PAw) and right arterial pressures ( $\overline{\mathrm{m}} \mathrm{RA})$ averaged over ten respiratory cycles; heart rate (HR), arterial and mixed venous blood gases. The following formulae were used for calculations: systemic vascular resistance (SVR, dyn.s. $\left.\mathrm{cm}^{-5}\right)=80 \cdot(\overline{\mathrm{m} A P}-\overline{\mathrm{mRA}})$ : $\mathrm{CO}$, pulmonary vascular resistance (PVR dyne.. $\mathrm{cm}^{-5}$ ) = 80.(mPAP-PAw): $\mathrm{CO}$, oxygen transport $\left(\mathrm{TO}_{2}\right.$, $\left.\mathrm{ml} / \mathrm{min} / \mathrm{m}^{2}\right)=$ arterial $\mathrm{O}_{2}$ content $x$ cardiac index $\times 10$. Coronary flow to the right ventricle was 
expressed by the difference of diastolic arterial and m RA pressures. ${ }^{9}$

The patients were allowed to rest $30 \mathrm{~min}$ after insertion of catheters and baseline determinations were performed when heart rate and vascular pressures were stable. All measurements were done first in the basal conditions and repeated $60 \mathrm{~min}$ after captopril $(0.25 \mathrm{mg} / \mathrm{kg})$, then oxygen was administered ( 2 litres/min given by nasal cannula) for 30 minutes and measurements were repeated.

The study was approved by the local ethical committee and informed consent obtained from all the patients.

\section{Results}

All values (Table I) are expressed as mean \pm standard deviation (s.d.). Differences between means were compared with a paired $t$ test.

Mean arterial pressure ( $\overline{\mathrm{m}} \mathrm{AP})$ was decreased after captopril $(P<0.05)$. In contrast to that captopril did not exhibit any significant pulmonary antihypertensive action; we found no changes in $\overline{\mathrm{m}} \mathrm{PAP}$ or in PVR. Cardiac output was decreased in all our patients but the difference was not statistically significant. It is important that in three patients the $\mathrm{CO}$ fell more than 1.5 litres $/ \mathrm{min}$. We found that the heart rate was reduced significantly after captopril. Coronary flow to the right ventricle, as expressed by the difference of diastolic arterial and mRA pressures, was reduced after captopril (from $74.4 \pm 15.8$ to $61.1 \pm 13 \mathrm{mmHg}$. $P<0.05$ ). There were no changes in arterial blood gases after captopril.

When $\mathrm{O}_{2}$ was given after captopril no significant changes in $\overline{\mathrm{m} P A P}, \mathrm{PVR}, \mathrm{SVR}, \mathrm{CO}$ and $\mathrm{HR}$ were observed.

\section{Discussion}

Within the pulmonary vascular bed, angiotensin I is converted to angiotensin II and bradykinin is degraded, both reactions being mediated by the angiotensin-converting enzyme, which is located on the luminal surface membrane of the pulmonary vascular endothelium. ${ }^{10}$ It has been demonstrated in animals that inhibition of angiotensin II formation by ACE inhibition can prevent pulmonary vascular changes induced by chronic alveolar hypoxia. ${ }^{11,12,13}$ In contrast others ${ }^{14,15}$ were not able to prevent hypoxic pulmonary vasoconstriction by saralasin or captopril.

Clinical results of the use of ACE inhibitors in the treatment of hypoxic pulmonary hypertension are also not consistent. Three recent reports ${ }^{4,6,16}$ suggest that captopril does not decrease pulmonary vascular resistance in patients with pulmonary hypertension resulting from chronic alveolar hypoxia. Bertoli et al. ${ }^{5}$ claimed that captopril improves pulmonary haemodynamics but the magnitude of the reported pulmonary artery pressure drop was of no clinical significance.

Table I Results

\begin{tabular}{|c|c|c|c|}
\hline & Baseline & Captopril & Oxygen \\
\hline $\mathrm{PaCO}_{2} \mathrm{mmHg}$ & $51.2 \pm 13.5$ & $50.3 \pm 12$ & $50.1 \pm 13$ \\
\hline $\mathrm{PaO}_{2} \mathrm{mmHg}$ & $42.8 \pm 8.4$ & $43.6 \pm 6.4$ & $71.8 \pm 11.5 \dagger$ \\
\hline$P \overline{\mathrm{v}} \mathrm{O}_{2} \mathrm{mmHg}$ & $30.4 \pm 5.4$ & $30.7 \pm 4.3$ & $38.15 \pm 5.7 \dagger$ \\
\hline $\mathrm{To}_{2} \mathrm{ml} / \mathrm{min} / \mathrm{m}^{2}$ & $682 \pm 186$ & $646.5 \pm 175.2$ & $759.2 \pm 288$ \\
\hline COlitres/min & $6.6 \pm 2.02$ & $6 \pm 2.1$ & $6 \pm 2.5$ \\
\hline \multicolumn{4}{|l|}{ Venous admixture } \\
\hline (\% of total blood flow) & $46.5 \pm 14$ & $39.5 \pm 10.7$ & - \\
\hline$\overline{\mathrm{m}} \mathrm{AP} \mathrm{mmHg}$ & $99.5 \pm 15.6$ & $83.5 \pm 12^{*}$ & $82.3 \pm 17$ \\
\hline$\overline{\mathrm{m} R A} \mathrm{mmHg}$ & $7.9 \pm 4$ & $7.7 \pm 4$ & $7.8 \pm 4$ \\
\hline $\mathrm{SVI} \mathrm{ml} /$ beat $/ \mathrm{m}^{2}$ & $40.2 \pm 12.5$ & $39.2 \pm 11.4$ & $40.6 \pm 16$ \\
\hline Diastolic AP- $\overline{\mathrm{m}} \mathrm{RA} \mathrm{mmHg}$ & $74.4 \pm 15.3$ & $61.1 \pm 13^{*}$ & $61.3 \pm 18.3$ \\
\hline SVR dyne $. \mathrm{s} . \mathrm{cm}^{-5}$ & $1192.3 \pm 451.6$ & $1109.5 \pm 416$ & $1098 \pm 453$ \\
\hline PAw mmHg & $7.7 \pm 5.2$ & $6.9 \pm 5.2$ & $6.25 \pm 3.3$ \\
\hline$\overline{\mathrm{mPAP}} \mathbf{\mathrm { mmHg }}$ & $34.1 \pm 10.1$ & $32.5 \pm 10.4$ & $29.7 \pm 8.8$ \\
\hline PVR dyne.s. $\mathrm{cm}^{-5}$ & $352 \pm 198.6$ & $395 \pm 212.5$ & $373.6 \pm 224$ \\
\hline $\mathrm{HR}$ beat $/ \mathrm{min}$ & $95 \pm 18.5$ & $88.6 \pm 12.5^{*}$ & $87 \pm 9.9$ \\
\hline
\end{tabular}

Definition of abbreviations: $P \mathrm{PaCO}_{2}=$ arterial $\mathrm{CO}_{2}, P \mathrm{PaO}_{2}=$ arterial $\mathrm{O}_{2}, P \bar{v} \mathrm{O}_{2}=$ mixed venous $P \mathrm{O}_{2}, \mathrm{To}_{2}=\mathrm{O}_{2}$ transport, $\mathrm{CO}=$ cardiac output. $\mathrm{AP}=$ systemic arterial pressure, $\mathrm{HR}=$ heart rate. $\mathrm{SVI}=$ stroke volume index.

Statistical analysis performed (1) between baseline and captopril, (2) between captopril and oxygen $\left({ }^{*} P<0.05, \dagger P<0.01\right)$ 
In our acute study in hypoxic COPD patients captopril was not shown to change pulmonary artery pressure and pulmonary vascular resistance, suggesting a probable lack of any role of angiotensin II in maintaining pulmonary hypoxic vascoconstriction. Although hypoxia inhibits ACE activity, the gross elevation of plasma renin activity observed in patients with chronic hypoxia may still cause increased angiotensin II levels. ${ }^{7}$ Apparent reduction in ACE activity has been demonstrated on ascent to high altitude ${ }^{18}$ and in patients with cor pulmonale and respiratory failure caused by COPD. ${ }^{19}$

There was a tendency for cardiac output to fall in our patients and coronary flow to the right ventricle was reduced in them after captopril. Ischaemia of the right ventricular myocardium is a

\section{References}

1. Sharp, D.N., Douglas, J.E., Coxon, R.J. \& Long, B. Low-dose captopril in chronic heart failure: acute haemodynamic effects and long-term treatment. Lancet 1980, ii: 1154-1157.

2. Levine, T.B. \& Cohn, J.N. Determinants of acute and long-term response to converting enzyme inhibitors in congestive heart failure. Am Heart $J$ 1982, 104: 11591163.

3. Edwards, C.R. \& Padfield, P.L. Angiotensinconverting enzyme inhibitors: past, present and bright future. Lancet 1985, i: 30-34.

4. Richard, C., Ricome, J.L., Rimailho, A., Conrad, M. \& Auzepy, P. Effects of captopril on pulmonary haemodynamics. Eur J Clin Pharmacol 1984, 27: 3539.

5. Bertoli, L., Fusco, M., Cicero, S., Micallet, E. \& Busnardo, I. Influence of ACE inhibition on pulmonary haemodynamics and function in patients in whom beta-blockers are contra-indicated. Postgrad Med J 1986, 62 (Suppl. 1): 47-51.

6. Zielinski, J., Hawrylkiemicz, I., Gorecka, D., Gluskowski, J. \& Koscinska, M. Captopril effects on pulmonary and systemic hemodynamics in chronic cor pulmonale. Chest 1986, 90: 562-565.

7. Che, S. \& Bavan, S. Pharmacology of pulmonary blood vessels. In: Widdicombe, J.G. Respiratory Pharmacology. Pergamon Press, Oxford, 1981.

8. Farber, M.O., Roberts, L.R., Weinberger, M.H., Robertson, G.L. \& Fineberg, N.S. Abnormalities of sodium and water handling in chronic obstructive lung disease. Arch Intern Med 1982, 142: 1326-1330.

9. Melot, C., Hallemans, R., Naeije, R., Mols, P. \& Lejeune, P. Deleterious effect of nifedipine on pulmonary gas exchange in chronic obstructive pulmonary disease. Ann Rev Respir Dis 130: 612-616.

10. Ryan, H.W., Ryan, U.S., Schultz, D.R., Whitaker, C., Chung, A. \& Dorer, F.E. Subcellular localization of pulmonary angiotensin-converting enzyme. Biochem $J$ 1975, 146: 497-499.

11. Zakheim, R.M., Mattiolo, L., Malteni, A., Mullis, limiting factor in response to pressure load and that can contribute to the fall of cardiac output. ${ }^{20}$

The absence of beneficial haemodynamic effects on pulmonary circulation is unlikely to be due to the small doses of captopril used in our study, because low doses $(25-37.5 \mathrm{mg} /$ day $)$ have proved effective in the treatment of congestive heart failure. ${ }^{1}$

The absence of an effect of captopril on pulmonary vascular resistance in patients with COPD may be due to the fact that angiotensin II has no significant role in maintaining hypoxic vascoconstriction. However, the absence of a vasodilator response to oxygen suggests that there may be irreversible structural changes in the pulmonary arterioles in such patients.

K.B. \& Bartley, J. Prevention of pulmonary vascular changes of chronic alveolar hypoxia by inhibition of angiotensin I-converting enzyme in the rat. Lab Invest 1975, 33: 57-61.

12. Weir, E.F. \& Chesle, E. Inhibition of angiotensin converting enzyme by SQ 20881 reduces hypoxic pulmonary hypertension. Circulation 1968, 2: 82 (Abstract).

13. Rabinovitsch, M., Gamble, W., Williams, G. \& Rein, L. SQ 1425 converting enzyme inhibitor diminished pulmonary artery hypertension secondary to chronic hypoxia in rat. Fed Proc 1980, 39: 765-781.

14. Hales, G.A., Rouse, E.T. \& Karemi, H. Failure of saralasin acetate, a competitive inhibitor of angiotensin II, to diminish alveoloar hypoxic vascoconstriction in the dog. Cardiovasc Res 1977, 11: 1541-1546.

15. Previtt, E.L., Leffler, C.W. \& Feline, H. Hypoxic pulmonary vascoconstriction is not blocked by the angiotensin I converting enzyme inhibitor, captopril. $J$ Cardiovasc Pharmacol 1981, 3: 293-298.

16. Boschetti, E., Tantucci, C., Cocchieri, M., Fornari, G., Grassi, V. \& Sorbini, C.A. Acute effect of captopril in hypoxic pulmonary hypertension. Respiration 1985, 48: 296-302.

17. Stalcup; A., Lipset, J.S., Legant, P.M., Leuenberger, P.J. \& Millins, R. Inhibition of converting enzyme activity by acute hypoxia in dogs. J Appl Physiol: Respirat Environ Exercise Physiol 1979, 46: 227-234.

18. Milledge, J.S., Catley, D.M., Ward, M.P., Williams, E.S. \& Clarke, C.R.A. Reninaldosterone and angiotensin converting enzyme during prolonged altitude exposure. J Appl Physiol 1983, 55: 699-702.

19. Neilly, J.B., Clark, C.J., Tweddel, A. et al. Transpulmonary angiotensin II formation in patients with chronic stable cor pulmonale. Am Rev Respir Dis 1987, 135: 891-895.

20. Wiedemann, H.P. \& Mathay, R.A. Acute right heart failure. Critical Care Clinics 1985, 1: 631-661. 